\title{
Al-Khwârizmî's Place and Importance in the History of Mathematics
}

\author{
Serbay DURAN ${ }^{1}$, Hüseyin SAMANCI ${ }^{1, *}$ \\ ${ }^{1}$ Department of Mathematics Education, University of Adiyaman, Adiyaman, Turkey
}

\begin{abstract}
The aim of this study is to introduce Muhammad ibn Mûsâ alKhwârizmî and his works in terms of history of mathematics and mathematics education. Muhammad ibn Musa al-Khwârizmî an Iraqi Muslim scholar and it is the first of the Muslim mathematicians who have contributed to this field by taking an important role in the progress of mathematics in his own period. He found the concept of Algorithm in mathematics. In some circles, he was given the nickname Abu Ilmi'lHâsûb (the father of the account). He carried out important studies in algebra, triangle, astronomy, geography and map drawing. Algebra has carried out systematic and logical studies on the solution of inequalities at second level in the development of the algebra. He with all these studies have contributed to mathematical science and today was a guide to the works done in the field of mathematics.
\end{abstract}

\section{Al-Khwârizmî's life}

Muhammad ibn Mûsâ al-Khwârizmî is an Iraqi Muslim scholar who lived in ninth century. Although the exact date of birth was unknown, he was born around 780s CE and died in 847 CE. He was called al-Khwârizmî and Abû Ja'far. The origin of the alKhwârizmî today is from "Khuwa" city, locates in south of the Aral Sea in Asia (Uzbekistan) His family moved to live in Baghdad, the center of knowledge for his period. He lived in Baghdad during the period of Abbasid Caliphate Ma'mûn [1-2].

He was always attached to Caliphate Ma'mun who was very generous to himself. Caliphate, worked in the House of Wisdom, where he founded for the scholars. At that time, House of Wisdom became famous in the fields of research, translation and publication. The scientists working there translated to Arabic, especially in scientific and philosophical works in Greek [1-2].

Al-Khwârizmî, in the library of Ma'mûn, benefited from many books and interested in mathematics, geography, astronomy, and history. He was also interested in scientific studies of Greek and Indian civilizations [2].

His reputation spread after he came out in the field of astronomy and mathematics and he was the first of the Muslim mathematicians who have contributed to this field by taking an important role in the progress of mathematics in his own period [2].

\footnotetext{
"Corresponding author: hsamanci@adiyaman.edu.tr
} 
He learned about account transactions, found the concept of Algorithm in mathematics. In some circles, he was given the nickname Abû Ilm al-Hâsûb (the Father of the Accounting) [3].

\section{Al-Khwârizmî in the field of mathematıcs}

Al-Khwârizmî important works in the field of mathematics were a result of his special research. He discussed the mathematics works on Greek and Indian civilizations before he developed the knowledge he gained on this issue. He showed a special interest in combining this knowledge with logic [2-3].

Al-Khwârizmî, carried out important studies in algebra, triangle, astronomy, geography and map drawing and in $830 \mathrm{CE}$ he wrote his work Kitâb al-Jabr wa'l Muqâbala. This term was translated as algebra in many languages with its English name. His work has followed a methodological and logical path to the solution of in the second degree inequalities [2].

Al-Khwârizmî's found the concept of al-Khwârizmîyya in mathematics and calculus that allowed him to be given the nickname of Father of Accounting. Algorithm and algebra terms belong to al-Khwârizmî's famous works in the field of mathematics. These two names are derived from Arabic terms الخوارزمي (al-Khwârizmî-algorithm) and الجبر (al-Jabralgebra) [3].

The concept of al-Khwârizmî's is derived from his name and is referred to English as He made a fundamental change in the concept of numbers and he used Arabic numbers. It brought the concept of zero as a number [3].

The works of al-Khwârizmî contributed to the transfer of Arabic numbers and the concept of algebra in mathematics to Europe and in the development of algebra science, systematic and logical studies have carried out on the solution of the second degree inequalities [3].

Al-Khwârizmî's great contribution to the calculations process, as well as the astronomy province, was revealed. He has done new research on triangles. He made the astronomy Zîj tables.These so-called Zîj tables have had a major impact on the tables that the Arabs created in the field of astronomy later [3].

Kitâb al-Jabr wa'l Muqâbala dealt with inheritance, wills, property sharing, commercial affairs and decision-making in relation among people, making calculations of two sites and dealing with engineering work [3].

One of the most important contributors of al-Khwârizmî's scientific work has been the addition of Ptolemy's geographical studies as both text and map [3-4].

Al-Khwârizmî made some adjustments by conducting special research on the geographical map created by Greek Ptolemy [3-4]. He also took part in geographical studies in order to reveal the first world map at that time and he wrote the most important work in the field of geography Surat al-Ard. This book explains the positions of the countries of his time [4].

\section{Al-Khwârizmî’s Kitâb al-Jabr wa'l Muqâbala}

Kitâb al-Jabr wa'l Muqâbala is the most important work that al-Khwârizmî wrote as a result of his important researches in mathematics [1-2]. Kitab al-Jabr was the first of the books on the systematic solution of linear and quadratic equations. He benefited from Greek and Indian sources in the past to gather and develop the knowledge he possesses. He showed a special interest in evaluating the knowledge obtained logically and combining that with his own considerations [3]. 
Al-Khwârizmî is obviously the father of algebra and shares the same narrative with Greek mathematician Diophantus. His theorem went into the areas of accountancy with his Latin translations [3].

Al-Khwârizmî has made algebra a science which to be benefited with full independence through its own method and rules [4]. He brought new terms to understand calculations and mathematical operations with it. Algebra, derived from the al-jabr term, is one of the two operations used to solve linear equations.

Al-Khwârizmî showed a great ability to understand and to grasp wide possibilities of algebra. He was able to solve engineering problems by algebraic methods. He alerted to the situation where it is impossible to find real value for the unknown and called it "impossible problems." This term remained in circulation until the late 18th century [5-6].

Al-Khwârizmî completely changed his understanding of numbers and he used the world of Arabic numbers. He brought the concept of zero. In the 12th century, he transferred the system of decimals from Indian numbers to the west. Then nine Arabic numbers have spread all over Europe [5]. When the West transferred their numbers from the Arabs, They moved with it their way of reading numbers from right to left [6].

Al-Khwârizmî's efforts were not limited to educating the West in writing numbers and calculations. It has gone beyond that complex math problems. His calculation of the rules even today still carry his name like a flag [7].

$\mathrm{He}$ is the first person to set the base for the calculation of the logarithm and this science is called by this name. The logarithm term derives from the Persian term "al-Khwârizm." The name is so known in Latin and algorithm is a division between calculus and algebra [7].

Al-Khwârizmî developed an applied method to find the area of the surfaces, the area of the circle, the area of a part of the circle and the area of the triangle. He arrived to calculate the size of the triple pyramid and the size of the quadratic pyramid and he put the method of multiplication of roots [8].

Al-Khwârizmî brought the terms of the equations of the first and second degrees and found the cues for them. After al-Khwârizmî, Muslim mathematicians came. They also worked on the development and dissemination of equations [2-3]. He is the first to replace the signs $(-$ or + ) when moved from one side of the equation to the other [3].

He wrote a booklet other than Kitâb al-Jabr wa'l Muqâbala that related to accounting science. He explained the usage system of Indian figures in this booklet and addition, subtraction, division, multiplication and calculation of fractions. This booklet was translated into Latin in the 12th century. The manuscript of the book is in the Vienna Balat Library. The second version of the book was found in Deir Salem and is now preserved in Heidelberg in Germany [5-6].

When he dealt with his book location of zero such as thirty-eight minus twenty-eight equals ten in the addition and subtraction operations, he said that In the subtraction operations If there was no more, we put zero. We do not leave the empty place until there is no confusion between the units digit and the dozens digit.

And he adds "the zero should be on the right of the number." Because the zero is on the left of the one. It does not change its value and does not make it ten [6].

We see that Western translators of Arabic sources have translated this system literally into Latin, and transferred from the system of writing and reading from the Arabs. In other words from right to left [7-8].

Al-Khwârizmî also corrected the researches of the Greek scientist Ptolemy in geography. He also oversaw the work of 70 geographies to complete the first map of the world known at the time. Of the most famous books in the geography book of the Earth image [8]. 


\section{Al-Khwârizmî’s works}

1. Kitâb al mukhtasar fi Hesab al jabr wa'l muqâbala

2. Kitâb fi Jourafia Sharh fihi Ârâi Ptolemy

3. Kitâb jadâvil li'n-Nujûm ve Harakâtiha min Mujelladayn

4. Kitâb fit-Tariqâti Ma'rifat al-Waqt bi Wasâtat al-Shams

5. Kitâb jamî fîhi bayna'l-Hisâb wa'l-Hendese wa'l-Mûsîgâ wa'l-Falak

6. Kitâb al-Amâl bi'l-Ousturlab

7. Kitab Sun'i'l-Ousturlab

8. Kitâb Wazhi fîhi Tariqât al-Jam wa't-Tarkh

9. Kitâb Sûrat al-Ard ve Jourafiatihâ

10. Kitâb Surat al-Ard

11. Kitâb al-Mârifa

12. Kitâb Zîj al- al-Khwârizmî al-Avval

13. Kitâb Zîj al-Khwârizmî al-Sânî

14. Risâlat al-Nisbat at-Takrîbiyya ve Qıymatih ar-Riyâziyya

15. Risâlat Wazhi fihâ Ma'nâ al-Wahdat al-Musta'mal fi'l-Masâhâti wa al-nujûm

16. Risâlet Zikri fîhâ Burhânan Âhira li Nazariyya Pisagor Mustakhdiman Musallas Qâim al-Zâviyat wa Mustevâ al-Sâqayn

17. Kitâb Rasm al-Ma'mûr

18. Kitâb al-Târīkh

19. Kitâb al-jam'i wa al-Tafrîq

20. Kitâb Hay'at al-Ard

21. Kitâb al-Rukhâma

22. Kitâb al-Mu'âmalât

\section{References}

1. H. Az-Ziriklî, Al-a'lâm, Dâru'l-'İlmi li'-1-Melâyîn, Beyrût, (2002).

2. K. Tarek, The Universal Effect for Arabic İslamic Civilization, İskenderiyye, (2009).

3. K. A. Salah, Ulemâu'l-Muslimîn fi'l-Ulûm ve'l-Teknolojia, (2010).

4. A. A. Al-Daffa, The Muslim Contribution to Mathematics, Atlantic Highlands, NJ: Humanities Press, (1977).

5. J. Hoyrup, Al-Khwârizmî, Ibn Turk, and the Liber Mensurationum, on the Origins of Islamic Algebra, Erdem 10.5, (1986).

6. S. Fuat, Al-Kitâb al-mukhtasar fî̀ hisâb al-jabr wa-l-muqâbala by Muhammad ibn Mûsâ al-Khwârizmî, Western Translations and Adaptations, (2006).

7. Van der Waerden, L. A. Bartel, history of algebra, from al-Khwārizmī to Emmy Noether, Springer Science \& Business Media, (2013).

8. R. Rashed, al-Khwârizmî le commencement de l'algèbre, Quadrature 23, (2009). 